\title{
The '85 New Space exhibition: Radical experiments and the academy
}

\section{Katherine Grube}

The '85 New Space exhibition (bawu xinkongjian huazhan 85新空间画展) opened on 2 December 1985, in the gallery of the Zhejiang Academy of Fine Arts (ZAFA, now China Art Academy), Hangzhou. ${ }^{1}$ The nine exhibiting artists, most of whom were ZAFA graduates, displayed sculptures, prints and oil paintings. Like many in the 1980s, these young artists rebelled against the academy and fine arts establishment through seemingly subtle experimentations with style and form. The graphic simplicity of their works was radical in its considered resistance to socialist realism's exaggerated expressiveness and idealised presentation of the human subject. The New Space artists' disregard for establishment conventions reflected a particular antipathy towards academic procedure and taste. Throughout the 1980s, the academy functioned as the symbol of institutional aesthetic conventions, the inculcating agent of institutionalised practices, and the physical agent of ideological and political enforcement. By electing to work in modernist idioms that depicted the urban everyday, the New Space artists eschewed the customary language of socialist realism in order to craft a wider cultural space in which to work more independently. Their self-conscious disengagement from conventional languages and styles reflected frustration with the ways in which bureaucracy and ideology not only determined artistic taste, value and style but also conditioned the production of and the critical response to art. The ' 85 New Space exhibition was organised during a time 
of intense cultural ferment, resulting from the economic reforms and political liberalisation introduced after the conclusion of the Cultural Revolution and the death of Mao Zedong in 1976. The gradual loosening of cultural controls provided access to new and previously banned information on art history and practices that went beyond socialist realism. At the same time, young artists who had spent their adolescence as Red Guards or 'sent down' youth

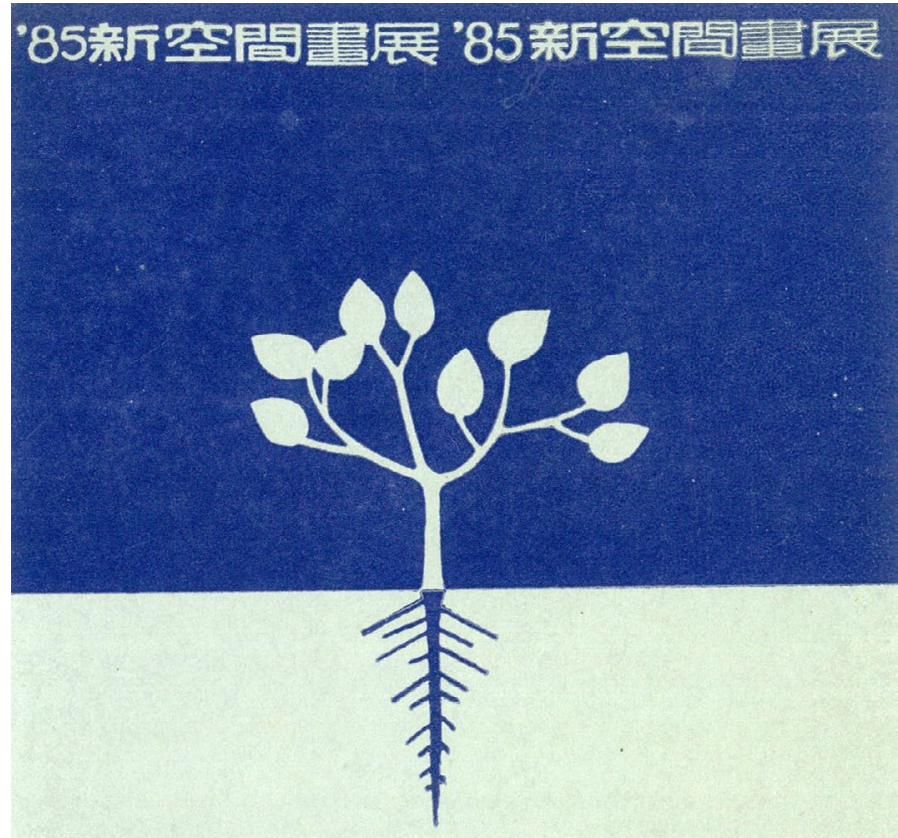

主办: 中国美术家协会浙江分会

青 年 创 作 社

地点: 浙江美院陈列馆

时间: 1985 年 12 月 2 日至 15 日

'85 New Space exhibition invitation. Image courtesy Zhang Peili.

85 新空间画展请柬。张培力惠允。 
(zhiqing 知青) in the countryside were encouraged to produce works critical of the revolutionary past and its excesses. Critiques of the Maoist period were also launched in a more radical, personal fashion by artist groups such as the Stars Group (xingxing huahui 星星画会) in Beijing, who explored different styles of international modernism in order to expand the space available for critiques of the status quo. However, for all their radical departures from socialist realist form and content, artists in the late 1970s and early 1980s continued to share a humanistic faith in the redemptive power of art that, on the one hand, revived the Enlightenment spirit of the May Fourth era, with its emphasis on public protest, and on the other hand, renewed academic realism as the highest aesthetic form. The Anti-Spiritual Pollution Campaign (qingchu jingshen wuran yundong 清除精神污染运动), launched in 1983, dampened the exuberance of the immediate post-Mao years, sending many rebellious artists into exile, while many of the more liberal cultural voices in the Chinese Communist Party were removed from leadership positions. ${ }^{2}$ The return to cultural conservatism produced widespread disillusionment, even within mainstream cultural and political institutions, and it was at this moment that the '85 New Space exhibition took place.

\section{The Sixth National Art Exhibition}

By 1984 such disillusionment was felt across the fine arts establishment, including in museums, professional organisations, fine arts academies and the fine arts press. For Zhang Peili and other New Space artists, their frustrations crystallised around the Sixth National Art Exhibition, held in Beijing in October that year. The exhibition displayed over three thousand works, most of them inoffensive and highly romanticised depictions of peasants, women or children. This return to the customary forms and subjects of Chinese socialist realism, and the conspicuous absence of innovative, unconventional or critical works, was perceived as bowing to the political demands of the Anti-Spiritual Pollution Campaign. Particularly surprising was the absence of so-called Scar art (shanghen meishu 伤痕美术), which emerged in the immediate post-Mao years, using a moody naturalism and themes of rural life or urban youth to criticise the Cultural Revolution's excesses. The Scar art movement resulted from artists' fatigue with producing idealised representations of politically and ideologically determined subjects, as well as their desire to confront the violence and abuse of the Cultural Revolution. ${ }^{3}$ Even though Scar art overtly challenged party and state narratives, Scar artists produced their cathartic and often critical compositions in a realist idiom, which allowed the movement to be readily incorporated into official art histories. At 
a time when official discourse and policy sought to repudiate the Cultural Revolution, to distance the party from the worst of the Maoist years, Scar art was almost instantaneously incorporated into the mainstream canon as an example of state-sanctioned self-criticism. Representative works, such as Cheng Conglin's A Certain Date. Snow. 1968 (1979) and Luo Zhongli's Father (1980), received major prizes at national exhibitions, were published in key art journals and were acquired by the China Art Gallery (now the National Art Museum of China).

In 1984, the socialist system continued to determine the conditions of artistic production in China, controlling systems of patronage, display and publication. The Sixth National Art Exhibition made explicit the limited potential for artistic creativity within a Byzantine system characterised by layers of bureaucracy that subjected far too much decision-making to political agendas, both personal and institutional. The exclusion of state-sanctioned Scar art from the Sixth National Art Exhibition provided young artists with a tangible example of the exhibition's conservatism. Their criticism of the exhibition focused on bureaucratic centralisation and the limits it placed on the diversification of artistic language. In an editorial published in the journal The Trend of Art Thought (Meishu sichao 美术思潮), the young critic and curator Fei Dawei captured frustrations with the stagnant cultural environment, writing, 'In the past, the theme was "Promote the Revolution and Boost Production". Now it is the "Four Modernisations". In the past, we painted Red Guards in military uniforms. Now we paint youthful workers in bell-bottom trousers. In terms of artistic concept, it remains unchanged from the Cultural Revolution.'4

To Zhang Peili and his Hangzhou classmates, the Sixth National Art Exhibition was an irritating reminder of how little had changed structurally in the 'reform era' (gaige kaifang 改革开放). The renewed political campaign of 1983, its targeting of individuals and its effective curbing of independent expression deepened their dissatisfaction with the arts establishment and the academy. The exclusion of the more idiosyncratic though still realist tableaux of recent art academy graduates, like Zhang Peili, sparked deep animosity that spurred many of these artists to form independent groups and organise exhibitions outside formal institutional channels, in a spontaneous outpouring of independent activity that critic Gao Minglu called the '85 New Wave Movement (bawu xinchao yundong 85新潮运动). ${ }^{5}$ In Hangzhou, Zhang and fellow artist Zha Li decided to create a physical and social space in which young artists could work. In the spring of 1985 they established two studios in suburban Hangzhou and started planning what was to become the '85 New Space exhibition. 


\section{Gathering in the Hangzhou suburbs}

The group of artists that gathered in these suburban Hangzhou studios is often referred to as the Zhejiang Youth Creation Society, or the Society of Young Artists (Zhejiang qingnian chuangzuoshe 浙江青年创作社), but such a formal title belies the group's ad hoc nature and ignores the fact that the 'society' was created to receive funding and other support from the Chinese Artists' Association (CAA) for an exhibition. ${ }^{6}$ From July 1984 the group held informal gatherings to discuss a possible exhibition. In December that year the artists formally rented studios, with financial support from the Zhejiang Branch of the CAA. In 1984, the group largely comprised ZAFA graduates and included Bao Jianfei, Song Ling, Wang Qiang, Xu Jin, Zhang Peili and Zha Li (though Zha emigrated to England on a government scholarship in May 1985). They were joined in July 1985 by Geng Jianyi, and later by the oil painter Wang Guojun, as well as Cao Xuelei, the only self-trained artist among them. ${ }^{7}$ The group never crafted a manifesto defining common artistic or philosophical commitments, but instead united around the desire to 'critically challenge the Chinese cultural establishment' through a future exhibition. ${ }^{8}$

The 'society' benefited from recent shifts within arts and cultural bureaucracy that favoured the promotion and support of young artists, professors and critics. In a speech on 22 October 1984, Deng Xiaoping had announced that older party cadres should 'unhesitatingly promote young and middle-aged cadres, especially those in their thirties and forties [as Comrade Chen Yun says]'. ${ }^{9}$ Deng's proclamation encouraged promotion based on professional expertise and talent rather than on political considerations. The impact on culture and the arts was immediate, transforming the type and quality of art produced across China.

The New Space artists were able to take advantage of this new administrative focus because of Zhang Peili's employment at the Zhejiang Branch of the CAA, from early 1985. Soon after his graduation from ZAFA in June 1984, Zhang had started teaching at the Hangzhou Academy of Arts and Craft, but repeated disputes with his department head caused him to switch work units to the CAA by the end of the year. By joining the CAA at a time when national leaders sought a transition of power in local and national party and state bodies, Zhang was able to channel institutional resources towards external projects, through which New Space artists received financial and promotional support from the organisation. The CAA paid for the artists' two studios and also purchased art supplies for the group. ${ }^{10}$ Additionally, the organisation 
included the '85 New Space exhibition in their official programming schedule, which widely publicised the exhibition (yet also meant that all works necessarily underwent a review process with local administrators prior to exhibition). ${ }^{11}$

Zhang also leveraged interregional rivalries to secure institutional support for the young artists. According to Zhang, the leader of the Zhejiang Branch of the CAA had returned from the Sixth National Art Exhibition dismayed by the province's under representation in the country's most prestigious exhibition and was eager to promote a new 'creative state of affairs'. ${ }^{12}$ This translated into supporting local youth and youth-led organisations in order to cultivate artistic innovation in accordance with Deng's national directive. The wry self-consciousness of the group's name, an allusion to the Creation Society (chuangzao she 创造社)an early twentieth-century literary movement and cultural project of national renewal-situated their efforts in a historical lineage familiar to even the most conservative bureaucrats.

When the '85 New Space exhibition opened on 2 December 1985, it was received as a radical statement by a group of young artists, their works sparking lively debates nationally and locally. Most of the exhibited sculptures, paintings and prints continued to pursue figuration but departed from the accepted styles and customary subject matter of the academy and mainstream fine arts establishment. Their portrayals of daily life drew on surrealism, Dada and modernist commercial art and design, while aspiring to an often deadpan neutrality of expression. Song Ling's ink-on-paper series People-Pipelines (1985) processed the dream imagery often associated with surrealism, in combinations of industrial workers, pipes and directional arrows. Geng and Zhang's painting series depicted, respectively, solitary hairdressers, and musicians and swimmers against shallow fields of colour. The melancholic overtones of their work are also seen in Xu Jin's compositions of lone figures in train stations, titled Dialogue (1985) and Zero Point (1985), as well as in Wang Guojun's Mechanic (1985), a precise, naturalistic depiction of a young man seemingly enclosed within industrial gears and machinery. Similar feelings of enclosure and alienation pervade Wang Qiang's sculpture Adagio of Symphony No. 5, Second Movement (1985). One of four sculptures included in the exhibition, Wang's Symphony encased a life-size plaster figure between two panes of glass approximately five feet long. The resulting vitrine bisected the gallery space and transformed the figure into 'a specimen' for examination. Cast from life, the headless and handless figure was poised with its arm raised as if preparing to give an orchestra its preparatory beat. It enacted a moment pregnant with anticipation for a future never to arrive. ${ }^{13} \mathrm{Zha}$ Li alone created abstract works, 
composed of flat geometric forms. Yet such simplicity in line and form was also explored in Bao Jianfei's lyrical and highly stylised print of a female nude reclining under the sun's rays, part of her series titled New Space.

In the context of a still highly regulated official system, the '85 New Space works were considered a radical break with institutional convention, for which they received significant attention locally and in the national fine arts press. The CAA's publication Meishu (Fine arts 美术)一then the most prestigious art publication in China-featured a multi-page colour insert on the show. In Hangzhou, two forums were organised at ZAFA to discuss the exhibition. It was also reported that every ZAFA department attended the show and organised formal discussions afterwards that allowed students 'to offer their opinions about the New Space exhibition'. ${ }^{14}$

As recent graduates of ZAFA, the young artists made that academy the most visible target of their criticism. Yet the exhibition also rebelled against conventional forms of academic and socialist realism in response to, on the one hand, their incongruity with the diverse sociocultural environment of the mid-1980s and, on the other, their association with the creative restrictions of the arts education system. In an editorial in Meishu, Bao Jianfei explicitly situated the exhibition as a considered resistance to the 'uniformity' of artistic 'language and method' in the academy, characterising the type of education she and other New Space artists received at ZAFA as 'an education in traditional Chinese painting guided by a national aesthetic sensibility and an academic training in the imported techniques of Western realist painting'. ${ }^{15}$ According to Bao, political demands stultified the development of realist practices and 'simplified' the thousand-year-old Chinese painting tradition. ${ }^{16}$ The resulting standardisation of technique, style and subject matter was 'incompatible with the heterogeneous and diverse perspectives brought about by the New Era'. ${ }^{17}$ Bao's criticism of her academic training and the academy's approach to art-making were informed, in part, by the disputes that had erupted during the 1985 graduation show at ZAFA.

\section{The 'naughty' students in the class of '85}

The oil painting department at ZAFA graduated only nine students across three studios in 1985, but its graduation show ignited a broad controversy that threatened the graduation of several students and resulted in three days of debate at the academy. Central to the controversy were educational reform 
and independent expression, the debates around which unfolded publicly in the pages of Meishu and the broadsheet Zhongguo meishu bao (Fine arts in China 中国美术报).

Supervised by Zheng Shengtian and Jin Yide, the 1985 graduation show departed in significant ways from previous graduate exhibitions. In 1983, Zheng had returned from a two-year fellowship at the University of Minnesota, where he had researched fine arts pedagogy, as well as modern and contemporary art in Europe and the United States. With Zheng at its helm, the 1985 graduate exhibition became an introduction to, and a proposition about, alternative approaches to studio practice and teaching. Zheng and Jin gave students far more responsibility and autonomy in determining the composition, subject matter and style of their graduation works. In addition, they allowed students to produce more than one work for exhibition, and to display a short explanatory wall text. ${ }^{18}$ Most radically, Zheng and Jin did away with the tedious approval procedure associated with the production of graduate works.

Typically, student works passed through up to five rounds of review and critique by faculty before being approved for production. The process moved steadily up the academic hierarchy, from studio supervisor to departmental committee, and through the three realist genres of suxie 速写, sumiao 素描 and secai 色彩. With successive approvals, student drafts increased in scale and likeness, beginning with a small rough pencil sketch (suxie) of the proposed work, followed by a full-scale pencil-and-ink sketch (sumiao) and then an impressionist colour sketch (secai). The process began in the first semester of their fourth year, around November, so that by April students could finally begin painting their graduation works. The review process ensured the ideological rectitude of a work's theme and its adequate demonstration of officially sanctioned technical skills. But, as Geng Jianyi recalls, it also ensured that the students had 'absolutely no interest' in their graduation works by the time of the exhibition. ${ }^{19}$

Zheng approached the 1985 graduation show as an opportunity for students to instead demonstrate their technical skills through self-determined themes and compositions. A handful of what Geng has referred to as 'naughty' students in the sculpture, printmaking and oil painting departments revelled in this new freedom, deliberately challenging the academy's sanctioned styles. ${ }^{20}$ Among the work of those students, Liu Dahong's two compositions Spring 
Cannot Be Confined (1985) and Plum Blossoms in Frozen Snow (1985) as well as Geng Jianyi's triptych The West (1985) and his Two People under a Light (1985) attracted the most scrutiny. Their works shared an intentionally naive simplicity that reduced pictorial elements, particularly human figures, to flat forms and blocks of colour. Both artists depicted youth in everyday settings, but the deadpan irreverence of Geng's works was singled out as 'particularly inferior' because his figures-students and peasantsexpressed 'indifferent personal relationships', incongruous with 'characters from contemporary times'. ${ }^{21}$ Conservative faculty members denounced the works for emphasising form over content, insufficiently demonstrating technical ability and departing significantly from themes that celebrated the reform era. ${ }^{22}$ They lamented that the works lacked 'nutritional' and 'spiritual value', and that the student artists had forsaken their 'responsibility' to 'inspire the enthusiasm of a billion people for the heroes that have emerged during the magnificent Four Modernisations and its revitalisation of China'. ${ }^{23}$

For their part, reform-minded professors at ZAFA perceived the graduation works as an important step towards the diversification of form and style, and critically linked the exhibition to broader educational reforms and new teaching methodologies. Zheng outlined the reformers' position in an August 1985 article in Meishu, titled 'Trends in Western Fine Arts Education'. ${ }^{24}$ Zheng's article begins with a discussion of the importance of arts education to American artists and institutions, then continues with a broad history of the fine arts academy, from the School of Drawing in Florence through to the present, before describing how contemporary curricula and institutions focus on both the 'transmission of ideas' and the 'teaching of craft'. ${ }^{25}$ To Zheng, the responsibility of a contemporary arts education was 'imparting knowledge' and 'cultivating technique'. ${ }^{26}$ Zheng's discussion of the diverse teaching methodologies in the United States, as well as the dual emphasis on intellectual and technical development, was a direct critique of the Chinese system, and he concluded his essay with a rhetorical proposal: 'In order to greet future challenges, isn't it necessary, in the process of building upon the successes and failures of the traditional and modern, Eastern and Western [models], to initiate discussion and work out a new design for art education in China today?'27

While debates took place in the academy, Geng and Zhang Peili formed their life-long friendship. Geng began working out of the artist studios in Hangzhou's suburbs, just as preparations began in earnest for the '85 New Space 
exhibition. He shared with the New Space artists a desire to disengage from the politicised artistic styles and subject matter associated with the fine arts mainstream; and his work, when viewed alongside stylistically and thematically similar compositions by Zhang Peili, Song Ling and Xu Jin, appeared as part of an emerging regional school or style, one that the prominent critic Gao Minglu would soon dub 'rational painting' (lixiang huihua 理性绘画). However, Gao's desire to define a unified school or movement frustrated Geng, Zhang and other New Space artists who were dismayed that their struggle for artistic independence was being ascribed an ideological position nonetheless.

\section{The irrationality of 'rational painting'}

Artists in Hangzhou recoiled from the sense of patriotic mission underlying Gao's New Wave movement. The apparent cohesion of a national cultural movement, under the title ' 85 New Wave, belied the diversity of local activity and produced uneasy interpretative categories, of which rational painting is perhaps most indicative. Rational painting yoked together stylistic tendencies shared by the Northern Art Group (beifang yishu qunti 北方艺术群体)一-working in Harbin, led by the artists Shu Qun and Wang Guangyi-and the New Space artists in Hangzhou. The interpretative rubric manufactured a coherent style that contradicted the very different theoretical and artistic investments of each group and ascribed a philosophical approach - 'rationality' (lixing 理性) - to their art-making. Gao described the rational painters as 'humanists [who] saw their art as an instrument for improving a backward society and reversing its cultural degeneration', and said they intended to 'create a new social and cultural order to replace the old'. ${ }^{28}$ Gao's humanistic interpretation of the artwork, and the nationalist ideals he describes, adheres to a vision of the purpose for art, culture and the artist that has been dominant in China since the 1910s. ${ }^{29}$ This understanding of art-making called upon artists to expose social and political problems in order to contribute to the making of a better world.

Although such patriotic ideals were not far from the Northern Art Group's expressed desire to 'stride forth at the forefront of history' and build a 'spirit' of rationality for the nation, the tradition of critical realism in the fine arts was precisely what artists in Hangzhou sought to overcome. ${ }^{30}$ Instead, they purposefully lampooned the pretensions and procedures of academic realist painting, subverting the nationalist ideals that had informed its development in China since the early twentieth century. They sought to discover 'art's meaning 
in our and our audience's everyday lives'. ${ }^{31}$ Artist Wang Qiang described the significant gap between the art-critical project of Gao and the self-proclaimed avant-garde and the practical project of artists in Hangzhou as follows: 'When critics tried to classify these groups during the 1980s, they made superficial judgements. They didn't fully understand the significance of our work. They judged things simply from the point of view of linguistic form ... the formal appearance of the artworks.' 32

The discursive impulse to situate the New Wave within a historical lineage of progressive, radical intellectual practice demonstrated the ways in which received beliefs and behaviours conditioned responses to and interpretations of art in 1980s China. To Zhang Peili and Geng Jianyi, the self-conscious avantgarde's consonance with, and desire to become, part of the establishment demonstrated not only the endurance of existing institutions but also the replication of institutional thinking within purportedly iconoclastic and independent circles. The reproduction of the establishment within the artistic avant-garde led Zhang, Geng and Song Ling to question oil painting's ability to subvert or circumvent prescribed narratives and interpretational frameworks. As the dominant and most prestigious fine arts discipline, oil painting seemingly possessed limited critical potential. The medium and its modes of presentation came to symbolise the ways in which institutional beliefs and behaviours were inculcated and reproduced, even subconsciously, in artist and audience alike.

In response to this perceived limitation, Zhang, Geng and Song formed the Pond Society (chi she 池社) in 1986, on the basis of their conviction that oil painting, and indeed other forms of academic painting, were not the exclusive 'medium for communicating ideas'. ${ }^{33}$ Between June and November of that year, in Hangzhou, the group created a series of site-specific performative interventions that explored the relationship between social space and the human form. Works in the series have come to be seen as some of China's most radical experimental art of the 1980s. In questioning the artwork's mode of reception and material format, the Pond Society was making a subversive comment on the nature of art itself, and, in so directing the purpose of art away from political and ideological commentary, they inaugurated artistic practices grounded in a self-consciously provocative spirit.

The Pond Society formed because of Zhang Peili, Geng Jianyi and others' frustrating engagement with the academy and broader fine arts mainstream in 1984 and 1985. The idealism expressed in the '85 New Space exhibition may 
have dissipated with the Anti-Bourgeois Liberalisation Campaign in 1987 and the violent suppression of student-led protests around Tiananmen Square in 1989, but its legacy is essential to the experimental attitudes and practices that took shape in Chinese art in the decades that followed. Their experiences at this time transformed a rebellious group of recent graduates into radical experimentalists committed to an alternative vision of art. Where Wang Guangyi and other Northern Art Group artists remained committed to iconography and to the painterly surface (and, in this sense, worked within the basic parameters of establishment practice), Zhang, Geng and others in Hangzhou fundamentally questioned basic conventions in a way that revealed structural mechanisms, as well as individual and communal behaviours and beliefs that constructed and maintained such conventions. Zhang and Geng transformed the social and political engagement with realism into a subversive commentary on the nature of representation itself, and in so doing articulated an alternative understanding of the purpose and function of art that was not only wholly original but absolutely vital to the continued emergence of experimental art practices in China.

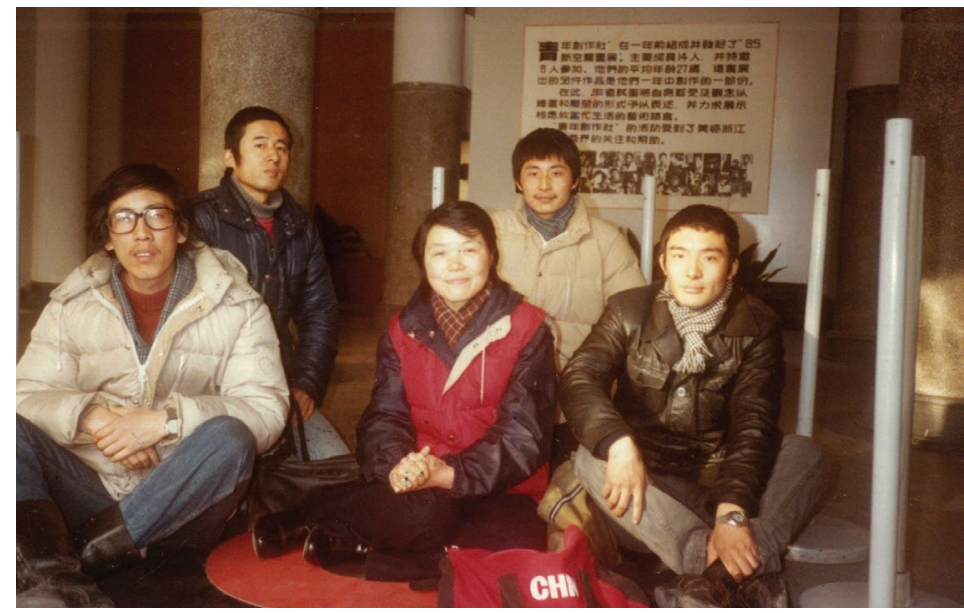

Artists in the '85 New Space exhibition (from left): Wang Qiang, Zhang Peili, Guan Ying, Geng Jianyi, Song Ling. Image courtesy of Zhang Peili.

85 新空间画展参展艺术家, 左起: 王强、张培力、关颖、耿建翌、宋陵。张培力惠允。 
1 While the '85 New Space exhibition included works of printmaking and sculpture, it predominantly comprised paintings; indeed, its Chinese title could literally be translated as "85 New Space painting exhibition'. This essay reflects the prominence of painting in the exhibition, focusing on the debates and controversy that roiled the Oil Painting Department at ZAFA, rather than on parallel debates that occurred in the Printmaking and Sculpture Departments.

2 In a well-known example, critic Li Xianting was removed from the editorial board of the journal Meishu [Fine Arts] during this time. For a discussion of the effect of the Anti-Spiritual Pollution Campaign on exhibition programming and works selected for the national exhibitions, see Jane DeBevoise, Between State and Market: Chinese Contemporary Art in the Post-Mao Era (Leiden: Brill, 2014), 18, 23.

3 Julia F. Andrews, Painters and Politics in the People's Republic of China, 1949-1979 (Berkeley: University of California Press, 1994), 393-96; Martina Köppel-Yang, Semiotic Warfare: The Chinese Avant-Garde, 1979-1989; A Semiotic Analysis (Hong Kong: Timezone 8, 2003), 24, 185-87; DeBevoise, Between State and Market, 28-32.

4 Fei Dawei, comp. 'Zhongyang yuan shushing guanyu diliujie quango meizhan zuotan jiyao' [Summary of the symposium about the Sixth National Art Exhibition held by teachers and students of the Central Academy of Fine Art], Meishu sichao [The Trend of Art Thought], no. 1 (1985): 11.

5 Gao Minglu, ' 85 xinchao yundong' [' 85 New Wave movement], Meishujia tongxun [Journal of artists], no. 3 (1986): 8.

6 Bao Jianfei, 'Women ji women de chuangzuo' [Our creations and us], Meishu [Fine arts] 218, no. 2 (1986): 48; Paul Gladston, 'Avant-Garde' Art Groups in China, 1979-1989 (Bristol: Intellect, 2013), 123-25; Shi Jiu [Zhang Peili], 'Guanyu "xin kongjian" yu "chishe"' [On 'New Space' and the 'Pond Society'], Meishu sichao [The Trend of Art Thought], no. 1 (1987): 16, trans. Kela Shang, in Contemporary Chinese Art: Primary Documents, ed. Wu Hung and Peggy Wang (New York: Museum of Modern Art, 2010), 83-89. On the naming of the group, see Zhang Peili, 'Materials of the Future: Documenting Contemporary Chinese Art from 1980-1990', interview for Asia Art Archive, 23 November 2008, 9, www.china1980s.org/files/interview/ zplftfinal_201104271739035788.pdf. In a conversation with the author (16 November 2016, Hangzhou), Geng Jianyi disputed that individual artists identified self-consciously as a formal group.

7 Shi, 'Guanyu "xin kongjian" yu "chishe"' [On 'New Space' and the 'Pond Society'], Meishu sichao [The Trend of Art Thought], no. 1 (1987): 16. See also Jiu, 'On New Space and the Pond Society (1987)', trans. Kela Shang, 85.

8 Shi, 16, and, trans. Kela Shang, 85.

9 Julia F. Andrews and Kuiyi Shen, The Art of Modern China (Berkeley: University of California Press, 2012), 214.

10 Shi, 'Guanyu "xin kongjian” yu "chishe”' [On 'New Space' and the 'Pond Society'], 16; trans. Kela Shang, 85-86.

11 Shi, trans. Kela Shang, 86.

12 Zhang, 'Materials of the Future', 9.

13 Shi, trans. Kela Shang, 85.

14 Shi Jiu [Zhang Peili], 'Guanyu “xinkongjian” huazhan de fanying' [On responses to the 'New Space' painting exhibition], Meishu [Fine arts] 218, no. 2 (1986): 47.

15 Bao Jianfei, "Women ji women de chuangzuo" [Our creations and us], Meishu [Fine arts] 218, no. 2 (1986): 48.

16 Bao, 48.

17 Bao, 48.

18 Jin Yide, 'Biye chuangzuo jiaoxue de tihui' [The experience of instructing graduate work], Meishu [Fine arts], no. 9 (1985): 42.

19 Geng Jianyi, interview with the author, 16 November 2016, Hangzhou.

20 Geng, interview, 16 November 2016.

21 'Zhemei biyesheng zuopin yinqi zhengyi' [Zhejiang Academy of Fine Arts graduate works cause controversy], Zhongguo meishu bao [Fine arts in China], no. 9 (21 September 1985): 23.

22 'Zhejiang meiyuan de yi chang panlun' [A debate at the Zhejiang Academy of Fine Arts], Meishu [Fine arts], no. 9 (1985): 16. 
23 Gang Xi, 'Lundian zhaibian-Zhejiang meiyuan biye chuangzuo taolun' [Argument excerpts-Zhejiang Academy of Fine Arts graduation works symposium], Meishu [Fine arts], no. 9 (1985): 27; Feng Xiao, 'Tan biye chuangzuo zhong de ji ge wenti-Zhejiang meiyuan biye chuangzuo taolunhui zhang de fayan' [Discussing several problems with graduation works - speech at the Zhejiang Academy of Fine Arts graduation works symposium], Meishu [Fine arts], no. 9 (1985): 23.

24 Zheng Shengtian, 'Xifang meishu jiaoyu qushi' [Trends in Western fine arts education], Meishu [Fine arts], no. 8 (1985): 62-64.

25 Zheng, 63 (Zheng's translation).

26 Zheng, 64.

27 Zheng, 64.

28 Gao Minglu, 'Conceptual Art with Anticonceptual Attitude: Mainland China, Taiwan, and Hong Kong', in Global Conceptualism: Points of Origin 1950s-1980s, ed. Stephen Bann (New York: Queens Museum of Art, 1999), 132.

29 In the mid-1910s, a movement among intellectuals emerged that called for the abolition of many aspects of China's social and cultural tradition. The New Culture Movement (xinwenhua yundong 新文化运动), which lasted into the 1920s, resulted from the political chaos surrounding the fall of the Qing dynasty in 1911, which led many intellectuals in China to conclude that political revolution without substantial cultural transformation would lead only to dictatorship and turmoil. Proponents of the New Culture Movement envisioned that political change followed intellectual and social change, and their severe critiques of traditional morality, and hierarchical and patriarchal social structures, were inherited by the Communist Party. Culture-in its literary and visual forms, in particular-emerged not only as the stimulus of a new society but also, through the depiction of social and cultural ills, as an agent of social change.

30 Shu Qun, 'Wei "beifang yishu qunti” chanshi' [An explanation of the Northern Art Group (1987)'], Meishu sichao [The Trend of Art Thought] 1 (1987): 36-39; trans. Phillip Bloom, in Wu and Wang, Primary Documents, 79, 81.

31 Jianfei Bao, 'Women ji women de chuangzuo' [Our creations and us], Meishu [Fine Arts], no. 2 (1986): 4849.

32 Gladston, 'Avant-Garde' Art Groups in China, 1979-1989, 142.

33 Shi, 'On New Space and the Pond Society (1987)', trans. Kela Shang, 87. Note, chi she can also be translated as 'pool society', chi meaning a pool of water. 


\title{
85新空间画展：激进实验与学院
}

\author{
古婷婷 \\ Katherine Grube
}

1985年12月2日，“85新空间画展” 在浙江美术学院（浙美）陈列馆举办, 展出了 雕塑、版画、油画等作品 ${ }^{1}$, 九位参展艺术家多数是浙美毕业生。像上世纪80年代的许 多人一样, 这些年轻艺术家通过看似微妙的风格和形式实验, 表达对学院和美术机构 的反抗。通过深思熟虑地抵抗社会主义现实主义的夸张表现手法、以及对理想化人物 形象的反思, 这些作品体现出激进的视觉简洁性。作为新近的学院毕业生, “新空间” 艺术家对权威的漠视反映了对学院派制式和审美的强烈反感。在整个 80 年代, 学院既 象征着传统机构审美传统, 又是制度化实践的灌输者, 对艺术强行施加政治和意识形 态影响。“新空间”艺术家使用描绘日常城市生活的现代主义艺术语言，从而避开社 会主义现实主义艺术手法, 以便创造更宽广、更能容纳独立创作的文化空间。与传统 艺术语言和风格的自觉脱离, 反映出这批艺术家的不满不仅限于官僚主义和意识形态 对艺术审美、价值和风格的垄断，也源于它们对艺术生产和批判性回应的限制。

“85新空间”展览出现的背景是文化大革命结束、1976年毛泽东去世后，因经济和 政治自由化改革引发的文化大繁荣。当文化控制逐渐放松，人们得以了解到社会主义 现实主义之外的艺术史和艺术创作，无论是新兴还是过去曾被禁止的内容。与此同 时, 青少年时期曾当过红卫兵或下乡知青的年轻艺术家们被鼓励创作批判革命历史 及其中过激行为的作品。对于毛时代的批评也是由北京星星画会等艺术家团体以激 进、个人的方式发起的, 他们探索了世界上不同风格的现代主义艺术, 从而拓展批判 现实的土壤。尽管这批活跃于 20 世纪 70 年代末和 80 年代早期的艺术家彻底背离了社 会主义现实主义的形式和内容, 他们却仍然继承了关于艺术救赎力量的人文主义信 念。这种信念一方面重振了五四传统和公民抗议的启蒙精神, 另一方面更新了作为最 高审美形式的学院派现实主义。1983年发起的“清除精神污染”运动挫伤了后毛泽 东时代的文化繁荣, 迫使许多有反叛意识的艺术家流亡海外; 而中共内部许多对文化 持自由态度的干部也被免除领导职务。2 即使在主流文化和政治机关中, 文化保守主 义的回归也造成了广泛的幻灭感, “85新空间”正是在这个时机中诞生。 


\section{第六届全国美展}

到了1984年, 整个美术界都感受到了这种幻灭, 包括博物馆、职业组织、美术学院 和美术出版社。对于张培力和其他 “新空间” 艺术家来说, 他们的挫败感可集中体现 于当年十月在北京举行的第六届全国美展。该展览展出了三千多件作品, 其中大多数 是对农民、妇女或儿童的无关痛痒的、高度浪漫化的描绘。这类作品回归中国社会主 义现实主义的惯用形式和主题, 明显缺乏创新、批判性和突破常规的创作。这一转向 被认为是屈服于清除精神污染运动的政治要求。尤其令人惊讶的是, 伤痕美术也没能 出现在这次展览中一一这一流派在毛时代结束后迅速出现, 利用沉郁的自然主义手法 描绘乡村生活或城市青年, 从而批判过激的文革运动。

伤痕美术运动源于艺术家对政治和意识形态先决的理想化表现形式的厌倦, 他们渴望 直面文化大革命中出现的暴力和伤害。3 尽管伤痕美术公然挑战党和国家的叙事, 但 艺术家们大多运用已有的现实主义艺术语言进行宣泄和批评, 使得伤痕美术很容易被 写入官方艺术史。当官方话语和政策试图否定文革, 从而使党与毛时代最黑暗的时 期保持距离时, 伤痕艺术几乎立即被纳入主流经典, 成为国家认可的自我批评之典 范。代表作品如程丛林的《1968年 $\times$ 月 $\times$ 日雪》（1980年）和罗中立的《父亲》

（1980年）, 都在国家级展会上获得重要奖项, 刊载于核心艺术期刊, 并被中国美 术馆收藏。

1984年, 社会主义制度继续控制着中国的艺术资本、展示和出版系统, 从而决定艺 术生产。第六届全国美展明确表明, 在这样一个极为复杂的体系中, 艺术创造力本身 并不占主导作用, 个人和机构的政治目的通过层层的官僚主义向艺术施加过多的决策 权。对年轻艺术家而言, 第六届美展排除了已被官方接纳的“伤痕艺术”，就是展览 保守主义的有力证据。他们对展览的批评主要集中在官僚集中化及其对艺术语言多样 化的限制上。青年评论家和策展人费大为在《美术思潮》杂志上发表的一篇社论中, 对 停滞不前的文化环境表达了沮丧之情。他写道: “过去画 “抓革命、促生产” , 现在 画 '建设四化' , 过去画穿军装的红卫兵, 现在画穿喇叭裤的青年工人。在创作方法 上、艺术观念上和 “文革” 时期几乎是一样的。” 4

对于张培力而言, 第六届全国美展再一次令人恼火的提醒他和他的杭州同学们, 改革 开放并没有带来多少结构上的变化。1983年重新掀起的政治运动以个人为目标, 有效 遏制了独立表达, 也加深了他们对艺术机构和学院的不满。以张培力为代表的年轻艺 术学院毕业生和他们具有个人特质却仍然属于现实主义的绘画被排除在展览之外, 这 在年轻艺术家中引发了强烈不满, 促使其中许多人自发形成了独立团体, 在正式的机 构渠道之外组织展览。这种自发的独立活动被评论家高名潞称作 “85新潮”。5 在杭 州, 张培力和同学查立决定创办一个年轻艺术家可以工作和社交的实体空间。1985年 春天，他们在杭州郊区建立了两个工作室，并开始筹划“85新空间”展览。 


\section{杭州郊区的聚会}

聚集在杭州郊区工作室的艺术家群体通常被称为“浙江青年创作社”，但这样的正式 名称掩盖了这一群体的临时性，也忽略了它成立的初衷，即获得美协提供的资金和支 持, 举办一场展览。6 从1984年7月开始, 该小组举行非正式聚会, 讨论这场可能的 展览。同年12月，艺术家们正式用中国美协下属浙江美协提供的资金租下了工作室。 在1984年, 该小组主要由浙美毕业生组成, 包括包剑斐、宋陵、王强、徐进、张培 力和查立（查立1985年5月通过公派留学移居英国）。耿建翌于1985年7月加入, 后来画家王国俊和小组中唯一一位自学成才的艺术家曹学雷也陆续加入。7 该组织从 未制定一个共同艺术或哲学承诺的宣言, 而是通过实施展览达成 “猛烈冲击中国文化 的堤岸” 的目标。8

创造社受益于其时艺术和文化官僚机构的转变, 这些转变有利于支持推广年轻艺术 家、教授和评论家。邓小平在 1984年10月22日的讲话中宣布, 老党员干部应该 “大胆地起用中青年干部, 特别是陈云同志讲要选拔三四十岁的年轻人。”9 邓的发 言鼓励以专业知识和人才而非政治考虑为基础进行晋升。这对文化艺术的影响立竿见 影, 改变了中国各地区艺术的类型和质量。

张培力于 1985年初在浙江美协就职, “新空间” 艺术家便得以利用这一新的政 策。1984年6月从浙美毕业后不久, 张培力到杭州工艺美校任教, 因与部门负责人多 次争执导致他在同年年底调职。在国家领导人在地方和中央寻求权力移交时期加入美 协, 这使得张培力能够将机构资源用于外部项目, “新空间”艺术家也因此获得美协 的财政和宣传支持。美协支付了艺术家的两个工作室租金以及材料费。10 此外，美协 还在其官方项目安排中加入了“85新空间” 展览, 这意味着展览得到了广泛宣传, 也 意味着所有作品必须在展出前由地方官员进行审查。11

张培力还利用地区竞争来确保获得体制对年轻艺术家的支持。据他讲述，浙江省美协 领导参观第六届全国美展时, 对本省在中国第一美展上参展作品不足感到很不满意, 希望加紧建设地方的“新的创作状态"12, 这也使得美协愿意依照邓小平的指示, 培养 有艺术创新性的青年活动和团体。“青年创作社” 的团体名称体现出他们讽刺性的自 我意识, 暗指二十世纪早期有志革新中国文化的文学团体 “创造社”，也将这一团体 置于保守官僚也熟悉的历史谱系之中。

“85新空间”展览于 1985年 12月2日开幕, 被认为是一群年轻艺术家的激进声明, 作品引发了当地和全国的激烈讨论。大多数展出的雕塑、绘画和版画作品仍然是具象 的, 但背离了学院和主流美术机构的风格和主题。他们对日常生活的描绘借鉴了超现 实主义、达达主义和现代主义的商业艺术和设计, 意图获得冷面般(deadpan)中立的 表达。宋陵的纸本水墨系列《人・管道》（1985年）处理了经常与超现实主义相关 的梦境图像, 包括工业工人、管道和方向箭头。耿建翌和张培力的绘画系列分别描绘 
了孤独的理发师, 以及浅景深色块背景中的音乐家和游泳者。这些画作中的忧郁色彩 也出现在徐进的火车站孤独旅人中, 如《对话》（1985年）和《零点》（1985年), 还有王国俊的《机械工》（1985年）中对困在工业齿轮和机械中的年轻人精确、自 然主义的描绘。类似的封闭和疏离感充斥着王强的《第5交响乐第2乐章开头的柔板》

（1985年）。作为展览中的四件雕塑之一, 《第5交响乐》将一个真人大小的石膏人 体塑像嵌入两个约5 英尺长的玻璃窗格中。玻璃展示柜将展览空间一分为二, 将塑像 转化为供人检查的 “标本” 。雕塑以真人为模型, 无头也无手, 一只手臂抬起, 似乎 在准备为交响乐队起拍。这是一个充满了可能性的时刻, 然而未来永远不会到来。13 只有查立一人展出了使用平面几何形式的抽象作品, 而包剑斐在日光下侧卧的裸女版 画不仅抒情且高度风格化, 也体现出与查立相似的线条和形式简练感, 这是她的系列 作品“新空间” 的一部分。

在一个仍受高度监管的官方体制背景下, “85新空间” 被认为是与制度的彻底决 裂, 因此受到当地和国家级美术纸媒的极大关注。中国最负盛名的艺术杂志、中国 美术家协会出版的《美术》印发了关于展览的彩色插页。在杭州, 浙江美院组织了两 个论坛来讨论展览。据称, 浙美的每个院系都参观了展览并组织正式讨论, 让学生们 就“新空间”发表意见。14

作为浙美的应届毕业生, 学院是这些年轻艺术家最明显的批判目标。然而, 展览还反 对了传统的学院派和社会主义现实主义。一方面, 学院派和社会主义现实主义不再符 合二十世纪八十年代中期多样化的社会文化环境, 另一方面, 它们与艺术教育系统 对创造性的限制息息相关。在《美术》杂志的一篇社论中, 包剑斐明确将 “85新空 间” 展览视为对学院中艺术 “语言和方法” 的 “统一性” 的抵制, 将她和其他“新空 间” 艺术家在浙江美院接受的教育描述为 “在民族审美精神指导下的中国传统绘画熏 陶” 和 “西方传入的写实绘画技巧的训练。” 15 包剑斐认为政治要求扼制了现实主义 创作的发展, 而且 “简化” 了逾千年的中国绘画传统, 16 由此产生的标准化技巧、 风格和主题无法适应“表现大时代潮流带来的多层次多角度的人的精神状态。” 17 1985年浙美毕业展期间爆发的争议也对包剑斐批判自己的美术训练和学院教授的创 作方法产生了影响。

\section{“不听话”的85届学生}

1985年, 浙江美院油画系仅有三个画室的九名学生毕业, 但他们的毕业展引发了广 泛争议, 导致学院进行了三天的辩论, 甚至威胁到几名学生是否能够毕业。争议的核 心是教育改革和独立表达, 围绕着《美术》杂志和《中国美术报》展开公开辩论。

不同于以往的毕业展览, 85届毕业展的指导教师是郑胜天和金一德。1983年, 郑胜 天完成明尼苏达大学为期两年的奖学金研修项目后回国。在明尼苏达, 他进行了美术 教育学及欧美现当代艺术的研究。在郑胜天的指导下, 85届毕业展介绍并提出了工作 
室实践和教学的不同方法。郑胜天和金一德在毕业作品的构图、主题和风格方面给予 学生更大的责任和自主权。此外, 他们还允许学生创作一件以上的作品, 并展示简短 的阐述文字。1 ${ }^{18}$ 最激进的一点是, 他们取消了毕业创作过程中繁琐的审批程序。

一般而言, 学生作品在被批准之前需经过最多五轮审查和点评, 在学院架构中, 通过 三个现实主义美术类别，即速写、素描和色彩，从画室的教学督导到院系学术委员会 层层上报。从最初构思作品的铅笔速写开始, 接着是全尺寸铅笔和钢笔素描, 然后是 印象主义的彩色素描（即色彩），随着各级批准，学生草稿的尺度和相似性也逐步增 加, 全部通过之后才能开始作画。这个过程始于大四第一学期的十一月左右, 直到次 年四月, 学生才能开始画他们的毕业作品。审查过程确保了作品主题在意识形态上过 关, 并体现了官方认可的艺术技巧。但是, 正如耿建翌回忆的那样, 这也确保了学生 们在展览开幕前早已对毕业作品彻底 “丧失兴趣”。19

郑胜天将85届毕业展视作一次让学生自行决定主题和构图从而展示创作技巧的机会。 在耿建翌的描述中, 雕塑、版画和油画系几位“不听话”的学生利用这一自由崭露头 角, 故意挑战学院派风格。20在这些学生中, 刘大鸿的两件画作《满园春色关不住》

（1985年）和《梅花欢喜漫天雪》（1985年）、耿建翌的三联画《西部》（1985 年）及《灯光下的两个人》（1985年）引起了最多关注。他们的作品都体现出一种 故作稚拙的简约感, 将画面元素, 特别是人物形象, 化约为平面形状和色块。两人 都描绘了日常生活中的年轻人，但耿建翌故意拒绝表达情感的画作被指责为特别低 劣，因为他画中的学生和农民体现了“人物关系的冷漠感”，不符合 “时代人物的特 征”。21 保守派教师谴责这些作品的形式大于内容, 不足以展示艺术技巧, 与改革 开放火热高昂的主旋律相去甚远。22 他们哀叹这些作品缺乏“营养价值”和“精 神价值”，而学生艺术家们已经放弃了他们的责任：“振兴中华实现四化的壮丽事 业中, 出现了许多可歌可泣的英雄人物, 我们应该去表现他们, 以激励十亿人前进 的热情。” 23

对有着改革思想的浙美教授而言, 毕业作品是走向形式和风格多样化的重要一步, 他 们将展览与更广泛的教育改革和新的教学方法联系起来。郑胜天1985年8月在《美 术》杂志发表题为《西方美术教育趋势》的文章, 陈述了改革者的立场。24 文章首 先讨论了艺术教育对美国艺术家和机构的重要性, 然后介绍美术院校的历史, 从佛 罗伦萨美术学院到当代，描述当代美育课程和机构如何关注 “意图的传达” 和 “技 艺的传授”。25对郑胜天来说，当代艺术教育的责任在于 “传授知识”和 “培养技 巧"。26 他对美国多元化教学方法以及知识和技巧双重强调的讨论是对中国体制的直接 批评。在论文结尾, 他提出了这样的设问: “为了迎接未来对我们的挑战, 是否也有 必要在总结古今中外功过得失的基础上, 对今天的中国美术教育模式进行研讨和重新 设计呢? ”。27 
在学院内部进行激烈辩论的同时, 耿建翌和张培力建立了终生的友谊。在 “85新 空间” 展览的准备工作开始之际, 耿建翌也开始在位于杭州郊区的艺术家工作室工 作。他与 “新空间” 艺术家一样意图脱离政治化的艺术风格和主流美术题材。如果把 他的作品与张培力、宋陵和徐进的风格和主题相似的作品放在一起, 可以看出一种全 新的地区流派或风格正在成型。著名评论家高名潞即将称之为“理性绘画”。然而, 高名潞想要定义一个内部统一的流派或运动的愿望使耿建翌、张培力和其他“新空 间” 艺术家感到沮丧, 他们并不希望自己争取艺术创作独立的斗争被归结为另一种 意识形态立场。

\section{“理性绘画”的非理性}

杭州艺术家们反对高名潞“85新潮” 运动所蕴含的爱国主义使命感，在“85新潮” 的大旗下讨论一种具有内聚力的全国性文化运动, 事实上掩盖了在地活动的多样性, 也产生了存在问题的阐释类别, 其中“理性绘画”可能是最具代表性的一种。“理性 绘画” 结合了哈尔滨以舒群和王广义为代表的北方艺术群体和杭州新空间艺术家们的 风格特征, 这一阐释类别意在产生一种连贯的风格, 这与两个群体截然不同的理论和 艺术探索形成了矛盾, 并为他们的创作赋予 “理性” 的哲学方法。高名潞将 “理性画 家”们描述为描述为一群“将艺术视为改进落后社会、扭转文化睢落的工具的人文主 义者”，他们打算 “创造一种新的社会文化秩序, 从而取代旧秩序”。高名潞对艺术 家创作的人文主义解读, 以及他所描述的国民主义理想, 延续了1910年代以来在中 国占主导地位的文艺目标和理想。29 这种对艺术的理解呼吁艺术家揭露社会和政治问 题, 从而促进创造一个更美好的世界。

虽然这种爱国理想与北方艺术群体“走在历史前面”、建立国家的理性“精神”的 愿望并不遥远, 批判现实主义的美术传统却恰恰是杭州艺术家试图克服的问题。30 他们故意讽刺学院派现实主义绘画的程式化和自命不凡, 颠覆了二十世纪初以来在中 国发展的民族主义理想, 试图在 “我们及我们的观众所熟悉的生活中发现艺术的涵 义。”31 艺术家王强认为高名潞的批评体系以及其它自我标榜的先锋艺术, 与杭州艺 术家们实施的在地项目之间存在着重大差别: “当评论者试图在20世纪80年代对这些 群体进行分类时，他们做出了肤浅的判断。他们并没有完全理解我们工作的重要性, 而只是通过艺术语言, 或者说艺术的外部形态来进行判断。” 32

这种话语冲动将85新潮置于一种进步、激进知识实践的历史系谱中, 体现出当时限定 对中国艺术作出反应和解释的认知和行为方式。对张培力和耿建翌而言, 先锋艺术与 体制的暗合、被体制吸纳的渴望, 不仅意味着现存体制的延续, 还揭示出官僚思想在 独立文化圈中亦极为普遍。先锋艺术中的体制重现令张培力、耿建翌和宋陵开始质疑 油画是否具有颠覆或规避现有叙事和阐释框架的能力。作为最负盛名、占主导地位的 美术类别, 油画的批判潜力似乎十分有限。这一媒介及其表现模式意味着体制的意志 和行为被灌输给艺术家和观众, 再通过他们的潜意识重现。 
为了回应这种局限性, 张培力、耿建翌和宋陵在 1986年创办了池社。他们坚信, 油 画以及其它学院派绘画模式并不是唯一的“思想交流媒介”。33 该小组于1986年6 月至 11 月间在杭州进行了一系列在地行为项目, 探讨了社会空间与人类形态之间的 关系, 被视为 20 世纪 80 年代最激进的实验创作之一。在质疑艺术作品的接收模式和 材料形态时, 池社对艺术的本质提出了颠覆性的论断。他们将艺术的目标从政治和意 识形态评价中转移出来, 开创了以有意识的挑畔精神为基础的艺术实践。

1984到1985年, 张培力和耿建翌等人对美术学院和主流美术界产生的挫败感催生 了池社。或许 “85新空间” 展览表达的理想主义随着1987年的“反对资产阶级自由 化运动” 和1989年对北京学生抗议活动的暴力镇压消失, 但其遗产对之后几十年中 国艺术中的实验态度和实践的形成至关重要。这一时期的经验使这群叛逆的美院毕业 生转变为致力于另类艺术视野的激进实验主义者。与此同时, 王广义和其他北方艺 术群体艺术家仍致力于图像学和绘画表面的工作, 也就是说, 他们的实践范围仍然处 于学院的基本参数之内。张培力、耿建翌和其他杭州艺术家则从根本上质疑了这些惯 例，揭露了结构机制、以及构建并维护惯例的个人和集体行为及主张。张培力和耿建 翌将现实主义的社会和政治参与转化为对表现本身性质的颠覆性评论, 这种实践清晰 地体现出他们对艺术目的和功能的另类理解, 这种理解不仅具有独创性, 也对中国实 验艺术的持续涌现至关重要。 
1. 尽管 “85新空间” 展览囊括了版画和雕塑, 展览的主体仍是绘画。它的中文名称事实上是 “85新空间画展”。 本文反映了绘画在展览中的突出地位, 主要关注围绕浙江美术学院油画系的讨论和争议, 而非版画和雕塑系的平行 争论。

2. 一个众所周知的例子是, 评论家栗宪庭在此期间被《美术》编委会除名。关于清除精神污染运动如何影响展览策 划和国家级展览的作品选择, 参见杜柏贞（Jane DeBevoise）：《国家与市场之间：后毛泽东时代的中国当代艺 术》，莱顿：博睿学术出版社, 2014年, 第18、23页。

3. 安雅兰 (Julia F. Andrews)：《中华人民共和国的画家和政治, 1949-1979》, 伯克利：加州大学伯克利 出版社，1994年，第393-96页；杨天娜（Martina Köppel-Yang）：《符号战：中国前卫艺术1979-1989》， 香港: 东八时区出版社, 2003年, 第24、185-187页; 杜柏贞：《国家与市场之间：后毛泽东时代的中国当代艺 术》, 莱顿: 博饕学术出版社, 2014年, 第28-32页。

4. 由费大为整理, 《中央美院师生关于第六届全国美展座谈纪要》, 《美术思潮》, 1985年第 1 期, 第 11 页。

5. 高名潞: 《85新潮运动》, 《美术家通讯》, 1986年第3期, 第8页。

6. 包剑斐: 《我们及我们的创作》, 《美术》, 1986年第2期, 第48页; 保罗 ·葛思谛 (Paul Gladston): 《中国1979至89的“前卫”艺术团体》，布里斯托：Intellect出版社, 2013年, 第123-25页; 石久 (张培 力）:《关于“新空间”与 “池社”》, Kela Shang译, 收于巫鸿、王必慈（Peggy Wang）编：《中国当代艺 术: 基本文献》, 纽约: 现代艺术博物馆, 2010年, 第83-89页。关于小组的命名, 参见张培力2008年 11 月28 日在亚洲艺术文献库的采访。耿建翌在2016年11月16日在杭州与笔者的谈话中, 表示这些艺术家并未自觉成为一 个正式的小组。

7. 石久: 《关于 “新空间”与 “池社”》, 《美术思潮》, 1987年第1期, 第18页; Kela Shang译, 收于巫鸿、王必 慈编：《中国当代艺术：基本文献》，纽约：现代艺术博物馆，2010年，第85页。

8. 同上, 第17页。

9. 安雅兰、沈揆一: 《中国现代艺术》, 伯克利: 加州大学出版社, 2012年, 第214页。

10. 石久, 《关于“新空间”与 “池社”》, Kela Shang译, 收于由巫鸿、王必慈编: 《中国当代艺术: 基本文献》, 纽约：现代艺术博物馆, 2010年, 第85-86页。

11.同上, 第86页。

12. 张培力访谈, 文字记录收于亚洲艺术文献库“未来的材料：记录1980-1990年的中国当代艺术”计划, 2008 年 11 月23日, 第9页, 链接: www.china1980s.org/files/interview/zplftfinal_201 104271739035788.pdf。最终访问 时间2016年12月30日。

13. 石久: 《关于“新空间”与 “池社”》, Kela Shang译, 收于巫鸿、王必慈编: 《中国当代艺术: 基本文献》, 纽约：现代艺术博物馆, 2010年, 第85页。

14. 石久（张培力）：《关于“新空间” 画展的反应》，《美术》，1986年第2期，总第218期，第47页。

15. 包剑斐: 《我们及我们的创作》, 第48页。

16. 同上。

17. 同上。

18. 金一德: 《毕业创作教学的体会》, 《美术》1985年第9期, 第42页。

19. 基于耿建翌在2016年11月16日在杭州与笔者的采访。

20. 同上。

21.《浙美毕业生作品引起争议》，《中国美术报》第9期，1985年9月21日，第23页。

22. 《浙江美院的一场辩论》，《美术》1985年第9期, 第16页。

23. 西岗: 《论点摘编一一浙江美院毕业创作讨论》, 《美术》1985年第9期, 第27页; 肖峰: 《谈毕业创作中的几个 问题一一浙江美院毕业创作讨论会上的发言》，《美术》1985年第9期, 第23页。 
24. 郑胜天: 《西方美术教育趋势》, 《美术》1985年第8期, 第62-64页。

25. 同上, 翻译由郑胜天提供。

26. 同上。

27. 同上。

28. 高名潞： 《观念艺术与反观念态度：中国大陆、台湾与香港》, 斯蒂芬 · 巴恩 (Stephen Bann) 编: 《国际观念主 义: 1950至80年代的起源》, 纽约: 皇后区美术馆, 1999年, 第132页。

29. 1910年代中期兴起的知识运动呼吁废除中国社会和文化传统中的许多方面。新文化运动一直持续到20世纪20年 代, 但是由于 1911 年清朝沦陷的政治混乱, 导致中国的许多知识分子得出结论, 认为没有实质性文化转型的政治革 命将只会导致独裁和动荡。新文化运动的支持者认为政治变革是在知识和社会变革之后进行的, 而中国共产党则继承 了他们对传统道德以及等级和父权制社会结构的严厉批判。文学与视觉文化的出现不仅催化了新兴社会, 也通过表现 社会和文化弊病成为社会变革的推动者。

30. 舒群: 《为北方艺术群体阐释》, 《美术思潮》, 1987年第1期, 第36-39页; Phillip Bloom译, 收于巫鸿、王必 慈编：《中国当代艺术：基本文献》，纽约：现代艺术博物馆，2010年，第79、81页。

31. 包剑斐: 《我们及我们的创作》, 第48-49页。

32. 保罗 ·葛思谛（Paul Gladston）：《中国1979至89的“前卫”艺术团体》，布里斯托：Intellect出版社, 2013 年, 第142页。

33. 石久（张培力）：《关于 “新空间”与 “池社”》, Kela Shang译, 收于巫鸿、王必慈编: 《中国当代艺术：基本 文献》，纽约：现代艺术博物馆，2010年，第87页。 


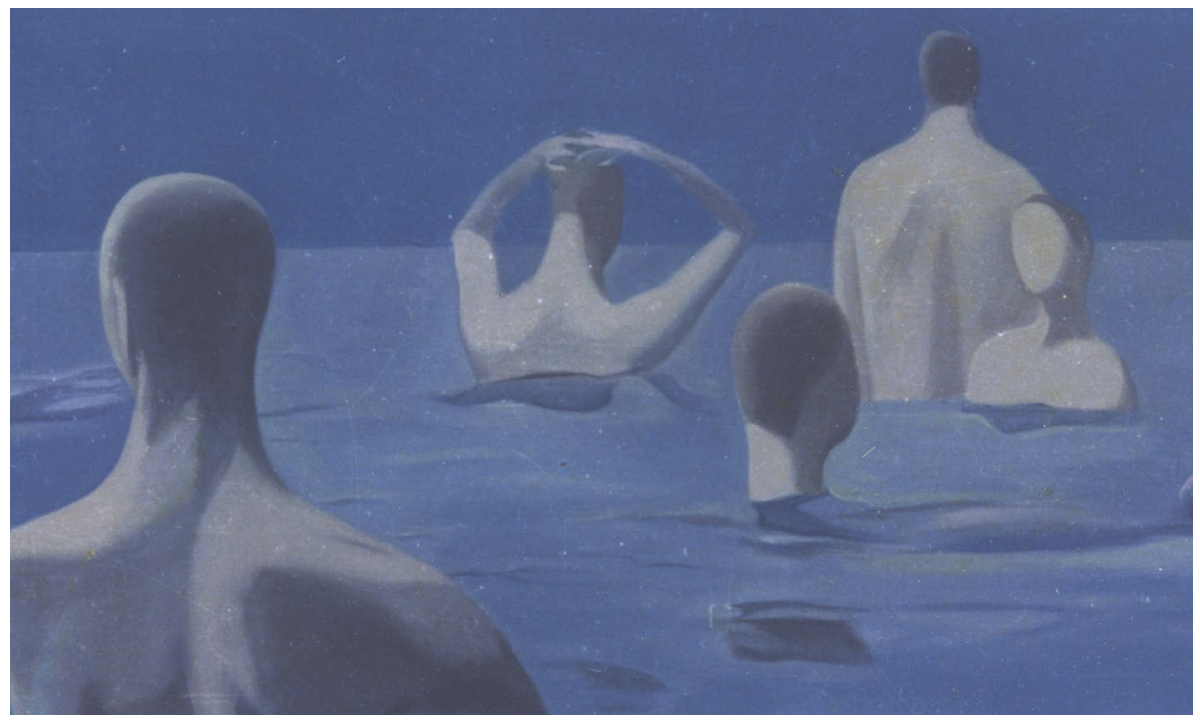

Swimmers in the Water, 1985, oil on canvas, $110 \times 135 \mathrm{~cm}$, one of four works exhibited in the ' 85 New Space exhibition. Image courtesy the artist and Boers-Li Gallery.

《水中的泳者》, 1985年, 布面油画, $110 \times 135 \mathrm{~cm}$, “85新空间画展”中展出的4幅画作之一。艺术家及博而励画廊惠允。 
This text is taken from Zhang Peili: From Painting to Video, edited by Olivier Krischer, published 2019 by ANU Press, The Australian National University, Canberra, Australia.

doi.org/10.22459/ZP.2019.04 